\title{
Predicting the Rationalization Factor that works on Accounting Fraud at Microfinance Institution
}

\author{
Mohammad Ghofirin ${ }^{1}$, Hafid Algristian ${ }^{2}$ \\ ${ }^{1}$ Faculty of Economics and Business, Universitas Nahdlatul Ulama Surabaya \\ ${ }^{2}$ Faculty of Medicine, Universitas Nahdlatul Ulama Surabaya
}

\begin{abstract}
ICSC (Indonesian Civil Servant Cooperative) is a microfinance institution that has been instrumental in realizing the welfare of households. ICSC has also grown in membership and wealth. The fraud risk is also a challenge for their efforts that are not yet fully with digital accounting technology. There are three factors of fraud according to triangle fraud theory, namely: pressure, opportunity, and rationalization. Among them, rationalization is the most important factor according to some empirical studies. The study aims to confirm the rationalization factor by investigating the relationship of ethical attitudes and personalities with accounting fraud. This explanative research took the Chief Financial Officer (CFO) of ICSC as samples by purposive sampling technique. Data collected through questionnaires are processed with multiple regression analysis techniques. The results of data processing show that significance value $0.814>0.05$; which means that simultaneous ethical and personality attitudes had no significant effect on accounting fraud.
\end{abstract}

Keywords: accounting fraud, ethical attitude, personality, microfinance institution

\section{Introduction}

The potential for accounting fraud is always there in every era, including in the current era, namely industry 4.0. Giroux, 2008 states that fraud is carried out in a sophisticated way. The current trend is that data is processed and operationalized through digital forms but unfortunately this still leads to new forms of corruption and fraud (Kruskopf, Lobbas, Meinander, Söderling, \& Martikainen, 2020). Digital data processing has indeed had a positive impact in the form of effectiveness and efficiency, but it still causes new forms of fraud, which is a negative impact (KÖKSAL, 2019). The potential for sophisticated accounting fraud, such as the case of AIG, WorldCom, Enron, and others, can cause economic crises and collapse around the world (Segal, 2016). All of this shows that the topic of fraud will always exist in every technology development that exists.

ICSC Surabaya has the potential to experience fraud as the number of its members and businesses grows. ICSC Surabaya has the highest number of members among 32 other types of cooperatives, reaching 42,476 people (BPS Kota Surabaya, 2017: 407). Global accounting fraud cases involve large companies as analyzed by Giroux, 2008. This indicates that the growing ICSC allows it to become a place for fraud practices. Pre-observation activities conducted by researchers explain that the turnover of the ICSC in Surabaya can achieve a sufficiently large value, around 5 billion rupiah per year.

There are other important things behind this research is the role of rationalization factors in fraud behavior. This study is based on the fraud theory triangle, which is a model of the factors causing fraud proposed by Cressey in 1950. The fraud triangle consists of pressure, opportunity, and rationalization. This fraud triangle has developed into the diamond of fraud by increasing the capacity factor (Ajekwe \& Ibiamke, 2017). Among these factors, psychological variables in the rationalization factor are a research topic that has a state of the art in the 21st century (Montesdeoca, Medina, \& 


\section{Kresna Social Science and Humanities Research \\ Proceedings of the International Conference On Ummah: \\ Digital Innovation, Humanities And Economy (ICU: DIHEc) 2020 \\ https:/doi.org/10.30874/ksshr.5}

Santana, 2019). Fraud will not occur if there is no rationalization, even though the pressure and opportunity components have existed (Nugraha \& Susanto, 2018). These psychological factors are composed of variables such as personality and attitudes (Cohen, Ding, Lesage, \& Stolowy, 2010). The existence of psychological variables such as attitudes and personality is very rare. To clarify the relationship between the two variables above, it is often based on two grand theories, namely the triangle fraud theory and planned behavior theory (Mustafidah, 2020; Owusu, Bekoe, Anokye, \& Okoe, 2020).

This paper aims to prove the influence of ethical attitudes and personality which is identified as the most determining factor in the occurrence of accounting fraud above. The discussion begins by identifying the level of influence, simultaneous and partial influence, and the nature of the relationship between the two.

\section{Literature Review}

\subsection{Fraud and Accounting Fraud}

Fraud and accounting fraud may be terms that are often heard and encountered. (Ajekwe \& Ibiamke, 2017) mentions that the two terms have a difference where accounting fraud is usually carried out by management to deceive users of financial statements while misappropriation of assets is carried out against an entity, most often by employees. They further explain accounting fraud as an act of material misstatement of financial statements or financial disclosures intentionally and illegally, thus having a direct impact on financial statements or financial disclosures.

The Association of Certified Fraud Examiners (ACFE) defines fraud as deliberate manipulation or misstatement by individuals or entities to bring illegal benefits to individuals or entities or other parties (Lal Bhasin, 2013). ACFE itself explains that in the concept of the fraud tree fraud is the same as accounting fraud. Most researchers use the term fraud for their operational definition of accounting fraud. This can be found in research of Okoye, E.I. \& Gbegi, 2013; Purnamasari \& Amaliah, 2015; Soltani, 2014, and others.

Fraud has various types and schemes. Fraud tree includes deviation of assets (asset misappropriation), financial statement fraud, and corruption (Association of Certified Fraud Examiners (Association of Certified Fraud Examiners (ACFE), 2014). The fraud scheme can be various, namely financial institution fraud, check and credit card fraud, insurance fraud, health care fraud, consumer fraud, and others. Description of these types and schemes reinforces the meaning of "fraud and accounting fraud are different terms" (Ajekwe \& Ibiamke, 2017).

\subsection{Accounting Fraud Grand Theory}

The grand theory of accounting fraud research refers to a general theory, namely the triangle fraud theory by Cressey (1950). The application of triangle fraud theory has evolved from embezzlement of positions to fraud examination in accounting. Malgwi \& Rakovski, 2009 revealed forms of fraud among students such as cheating. Day, 2010 also uses the concept of triangle fraud for cases of 'credit crises' arising from failures in organizational decision-making processes. These two examples at least have explained that the triangle fraud theory is basically not only about accounting. At this point, the difference between accounting fraud and the mentioned fraud Ajekwe \& Ibiamke, 2017 becomes clearer. This paper deals with fraud in accounting so that operationally the term used is accounting fraud. There is also a fraud study that analyses it from a combination of triangle fraud theory with the theory of planned behavior (TPB). This was modeled by Cohen et al., 2010 as below. 


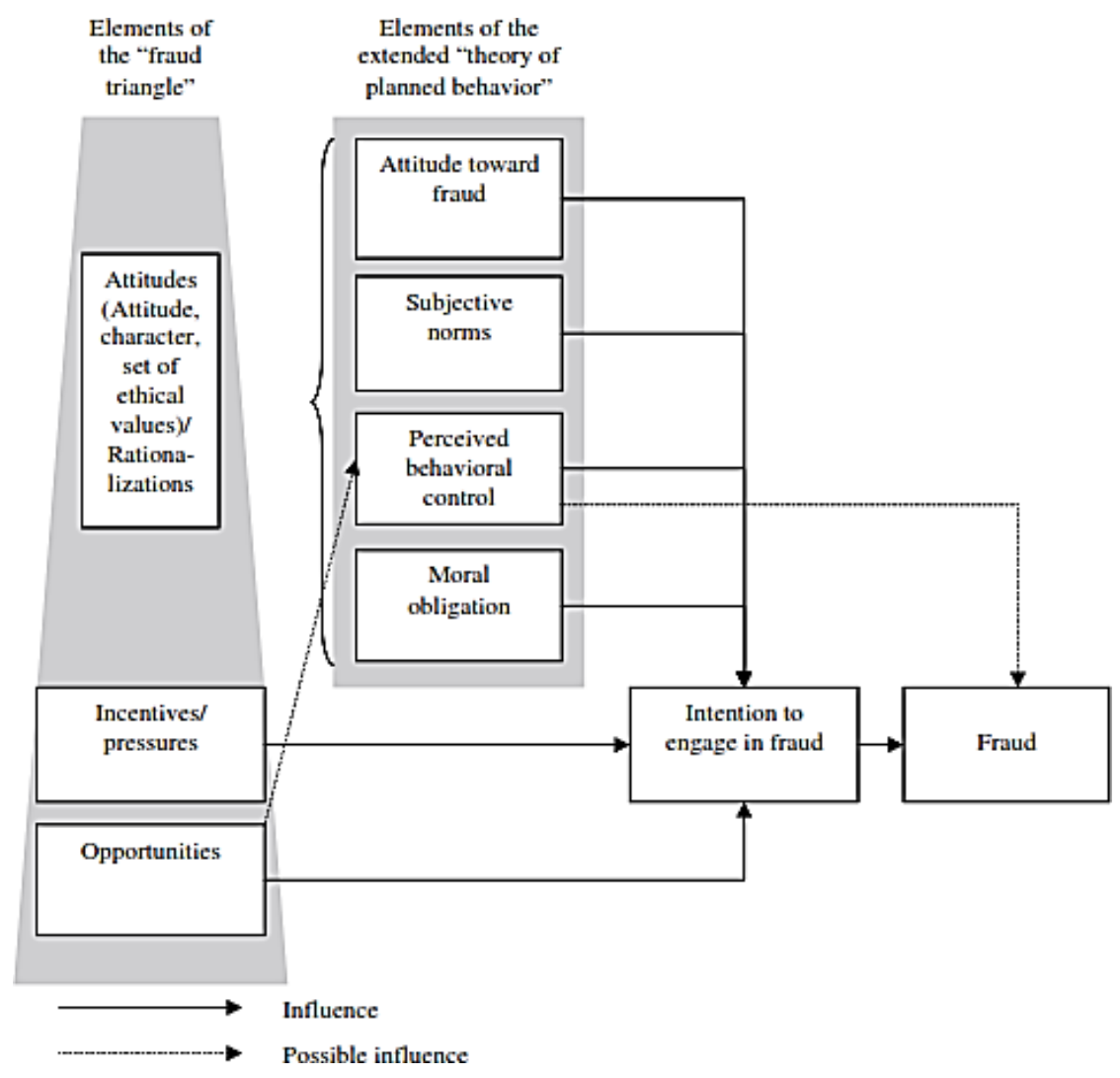

Figure 1. Combination of Fraud Triangle and Theory of Planned Behavior (Cohen et al., 2010)

Based on the model above, it is known that fraud occurs due to opportunity, pressure, and rationalization factors. In this figure, the three fraud factors influence interest in fraud, namely variables that have a direct effect on fraud. The picture also confirms that attitudes and personality are part of the rationalization factor. Figure 1 provides an explanation that ethical values are part of attitudes in this rationalization factor. This research is based on this. The ethical attitude referred to is ethical values in the accounting profession.

\subsection{Ethical Attitude and Personality Traits}

Conroy, Emerson, \& Pons, 2010 explain that ethical attitudes include a formal professional code that shows motivation and commitment to practice and the capacity to respond to others. Therefore, ethical attitudes are related to the formal code of one's profession as explained in the ethical concept of Bertends, that the definition of ethics can be divided into three, namely: (1) moral values and norms that become the guidelines for a person or group in regulating behavior practice, (2) a collection of principles or moral values (code of ethics), and (3) knowledge of good or bad. Thus, ethical attitudes can be defined as attitudes that refer to a person's professional code of ethics. The ethical attitude referred to here is developed based on the code of ethics for Indonesian accountants established by the IAI VIII Congress in Jakarta in 1998.

Personality (psyche) is the whole of thoughts, feelings and behavior, awareness and unconsciousness (Alwisol, 2009). A person's personality can experience disorders. According to Gabbard, 2014 personality disorders can be grouped into cluster A (suspicious), cluster B (emotional and impulsive), and cluster C (anxious). Fraud itself has the potential to be committed mostly by people in cluster B personality, especially that have antisocial behaviors or disorders. Individuals with antisocial personality disorder tend to have a long history of violations of the rights of others (Algristian \& Muljohardjono, 2018). 


\section{Kresna Social Science and Humanities Research \\ Proceedings of the International Conference On Ummah: \\ Digital Innovation, Humanities And Economy (ICU: DIHEc) 2020 \\ https:/doi.org/10.30874/ksshr.5}

\subsection{Ethical Attitudes and Personality towards Accounting Fraud}

There is some empirical evidence that explains the relationship between attitudes towards fraud. Mathenge, 2014 examines ethical attitudes towards employee corruption where the results show that the higher the ethical attitude, the smaller the fraudulent activity. This means that ethical attitudes have a negative effect on fraud behavior. This is also in line with the results of research Fernandhytia \& Muslichah, 2020 and Said et al., 2017 that ethical attitudes are negatively related to fraud from the employees studied. Personality also affects the occurrence of fraud. Individuals who commit fraud must have a strong ego and great confidence that they will not be detected (Abdullahi \& Mansor, 2015). In general, fraudsters are characterized by such attitude include someone who is driven to succeed at all costs, is selfish, confident, and often narcissistic. In general, personality is a determinant of behavior as illustrated in research of Tsao \& Chang, 2010 that such kind of economic behavior can be explained well using the five factor model, which consists of openness to experience, conscientiousness, agreeableness, extraversion, and neuroticism.

\section{Method}

The data of this study were taken from 33 respondents of accounting employees at various ICSCs in Surabaya who had a turnover of above 5 billion rupiah. Data collection was carried out in July-August 2019. Respondents of this study were 33 Chief Finance Officers (CFO ICSC) from all over Surabaya. International fraud cases show that the perpetrators are many (CFO), such as employees and managers as well as what happened in Indonesia (ACFE, 2014). Data was collected in July 2019 with a questionnaire technique where accounting fraud was developed based on ACFE 2014, ethical attitudes were developed based on the guidelines for Indonesian accounting ethics issued by the Indonesian Institute of Accountants (IAI), the higher the score, the higher the ethical attitude. Personality questionnaire was developed from the 12 items of Newcastle Personality Inventory by Nettle, 2007. However, this study used the assessment that the higher the score, the more flexible one's personality is, and the lower the score, the stiffer a person's personality is. The results of the validity test are described in table 1. The results of the questionnaire were processed using multiple regression techniques where the provisions of the hypothesis testing results were as follows.

(1) If value Sig. $<0.05$, there is a significant effect of ethical attitudes and personality directly on accounting fraud $\left(\mathrm{H}_{\mathrm{a}}\right.$ accepted)

(2) If value Sig. $>0.05$, there is a significant effect of ethical attitudes and personality directly on accounting fraud $\left(\mathrm{H}_{0}\right.$ accepted)

\section{Result and Discussion}

\subsection{Classic assumption test}

Regression analysis is performed after testing the classical assumptions as a requirement. The classical assumption test includes normality test, multicollinearity test, and heteroscedasticity test. Meanwhile, the autocorrelation test was not carried out because the research data was not time series data. The results of the normality test using the One Sample Kolmogorov-Smirnov Test show the $p<0.05$, which means that the data is not normally distributed. Furthermore, the Variance Inflation Factor (VIF) value is $1.085<10$, which means that there is no multicollinearity between the existing independent variables. The last classic assumption test is the heteroscedasticity test using a scatterplot. The results show that it is known that the dots do not form a clear pattern, and the dots spread above and below the 0 on the $\mathrm{Y}$ axis so that it can be concluded that there is no heteroscedasticity problem in the regression model. The scatterplot image in the heteroscedasticity test is in Figure 2 below. 


\section{Kresna Social Science and Humanities Research}

Proceedings of the International Conference On Ummah:

Digital Innovation, Humanities And Economy (ICU: DIHEc) 2020 https:/doi.org/10.30874/ksshr.5

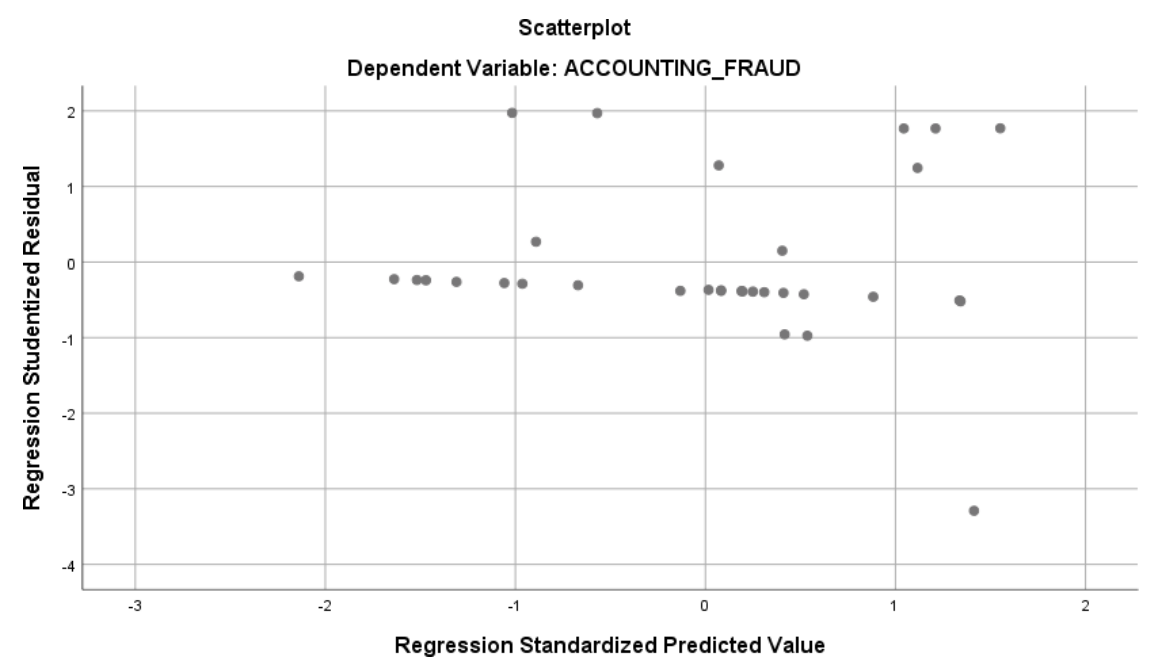

Figure 2. Heteroscedasticity test with scatterplot

\subsection{Simultaneous and Partial Influence}

Before analyzing the simultaneous and partial effects, it is necessary to look at the coefficient of determination (R2) of one of the regression outputs. The coefficient of determination (R2) is 0.119 or (11.9\%). This shows that $11.9 \%$ of Accounting Fraud in the ICSC Surabaya environment is influenced by the variables of ethical attitudes and personality. Meanwhile, $88.1 \%$ is influenced by other variables which are not included in this research model.

The next regression output shows the simultaneous effect of ethical attitudes and personality on accounting fraud. The results of the F test, which is shown by the ANOVA output table, show that the sig. 0.814>0.05, then $\mathrm{H}_{0}$ is accepted and $\mathrm{H}_{\mathrm{a}}$ is rejected so that the conclusion, ethical attitudes and personality simultaneously do not have a significant effect on accounting fraud.

Finally, the regression output shows the existence of a partial effect in the $t$ test. The overall $t$ test results in the regression analysis are shown in table 1.

Table 1. Final regression analysis*

\begin{tabular}{|c|c|c|c|c|c|c|}
\hline & \multirow[t]{2}{*}{ Model } & \multicolumn{2}{|c|}{$\begin{array}{c}\text { Unstandardized } \\
\text { Coefficients }\end{array}$} & \multirow{2}{*}{$\begin{array}{c}\text { Standardized } \\
\text { Coefficients } \\
\text { Beta }\end{array}$} & \multirow[t]{2}{*}{$\mathbf{T}$} & \multirow[t]{2}{*}{ Sig. } \\
\hline & & $\mathrm{B}$ & Std. Error & & & \\
\hline \multirow[t]{3}{*}{1} & (Constant) & 3.517 & 1.491 & & 2.359 & .025 \\
\hline & Ethical attitude & -.243 & .418 & -.111 & -.580 & .566 \\
\hline & Personality & -.020 & .194 & -.020 & -.103 & .918 \\
\hline
\end{tabular}

Based on the table above, it is known that:

a) Ethical Attitude (X1)

Significance value is $>0.05$, means that $\mathrm{H}_{\mathrm{a}}$ is rejected and $\mathrm{H}_{0}$ is accepted, meaning that partially ethical attitudes have no significant effect on accounting fraud. In addition, the B coefficient is negative, meaning that there is a negative relationship between ethical attitudes and accounting fraud, the higher the ethical attitude, the lower the occurrence of accounting fraud, and vice versa.

b) Personality (X2)

Significance value is $>0.05$, means that $\mathrm{H}_{\mathrm{a}}$ is rejected and $\mathrm{H}_{0}$ is accepted, meaning that partially personality does not have a significant effect on accounting fraud. The B coefficient is negative, 


\section{Kresna Social Science and Humanities Research \\ Proceedings of the International Conference On Ummah: \\ Digital Innovation, Humanities And Economy (ICU: DIHEc) 2020 \\ https:/doi.org/10.30874/ksshr.5}

meaning that there is a negative relationship between personality traits and accounting fraud, the higher (flexible) personality, the lower the occurrence of accounting fraud, and vice versa.

\section{Discussion}

This study aims to find the influence of ethical attitudes and employee personality on accounting fraud. Ethical attitudes and personality only have a potential influence of less than $20 \%$ while the rest is obtained from influences outside these two things. The simultaneous and partial effect shows that the two independent variables tested do not have a significant effect on accounting fraud. The insignificance of the influence of this rationalization factor is in line with the research findings (Utomo, 2018). The insignificance of this factor is possible because the ICSC applies an ethical attitude and does not use personality considerations in preventing fraud in ICSC.

The results also explain the nature of the relationship between ethical attitudes and personality. Ethical attitudes are negatively related to accounting fraud. This is in line with Fernandhytia \& Muslichah, 2020, Mathenge, 2014, and Said et al., 2017 that ethical attitudes are negatively related to fraud. the more ethical the attitude of cooperative accounting employees is, the more avoidance of accounting fraud and vice versa. This is the basis for the cultivation of accounting ethics in employees. Accounting ethics that need to be instilled in accordance with those published by IAI, include: (1) professional responsibility, (2) public interest, (3) integrity, (4) objectivity, (5) professional competence and prudence, (6) confidentiality, (7) professional behavior, and (8) technical standards as indicators for developing research instruments.

This study shows a negative correlation between personality scores and accounting fraud scores. The higher the personality score, the lower the accounting fraud score, and vice versa. A high personality score indicates a personality that is flexible and adaptable to situations, while a low personality score indicates a rigid personality. This study shows that the stiffer a person's personality is, the higher a person's tendency to commit accounting fraud (Cohen et al., 2010). A rigid personality indicates a person's low ability to adapt to situations, so that there is a tendency for someone to break through existing rules. It is not able to respond to limitations with creativity, but rather imposes rules to conform to his/her standards. A rigid personality that can come from all personality clusters, but a personality that clearly has a high potential for violating social norms is an antisocial personality in cluster B (Wallang \& Taylor, 2012).

\section{Conclusion}

This study has attempted to prove the ethical attitudes and personality of ICSC employees towards accounting fraud. This study shows that ethical attitudes and personality have a negative correlation even though they do not have a significant effect on accounting fraud. In the future, research is needed on the influence of organizational behavior and other components of the fraud diamond on the incidence of accounting fraud, including intervention regarding ethical attitudes in a financial institution.

\section{Acknowledgments}

Researchers would like to thank the respondents of the ICSC CFO in Surabaya who responded to our questionnaire voluntarily. 


\section{Kresna Social Science and Humanities Research \\ Proceedings of the International Conference On Ummah: \\ Digital Innovation, Humanities And Economy (ICU: DIHEc) 2020 \\ https:/doi.org/10.30874/ksshr.5}

\section{REFERENCES}

Abdullahi, R., \& Mansor, N. (2015). Fraud Triangle Theory and Fraud Diamond Theory . Understanding the Convergent and Divergent For Future Research. International Journal of Academic Research in Accounting, Finance and Management Sciences, 5(4), 38-45. https://doi.org/10.6007/IJARAFMS/v5-3/1823

Ajekwe, C. C. M., \& Ibiamke, A. (2017). Accounting Frauds: A Review of Literature. IOSR Journal of Humanities and Social Science, 22(04), 38-47. https://doi.org/10.9790/0837-2204083847

Algristian, H., \& Muljohardjono, H. (2018). Psikodinamika Fraudster dalam Sudut Pandang Ilmu Psikiatri. Medical and Health Science Journal, 2(1), 23-30. Retrieved from http://journal.unusa.ac.id/index.php/mhsj/article/view/593 Alwisol. (2009). Psikologi Kepribadian. Malang: UMM.

Association of Certified Fraud Examiners (ACFE). (2014). Fraud Examiners Manual (2014 International Edition). Texas - USA: ACFE.

Cohen, J., Ding, Y., Lesage, C., \& Stolowy, H. (2010). Corporate Fraud and Managers' Behavior: Evidence from the Press. Journal of Business Ethics, 95(SUPPL. 2), 271-315. https://doi.org/10.1007/s10551-011-0857-2

Conroy, S. J., Emerson, T. L. N., \& Pons, F. (2010). Ethical Attitudes of Accounting Practitioners : Are Rank and Ethical Attitudes Ethical Attitudes of Accounting Practitioners : Are Rank and Ethical Attitudes Related? Journal of Business Ethics, 91(August 2014), 183-194. https://doi.org/10.1007/s10551-009-0076-2

Day, R. (2010). Applying the Fraud Triangle Model to the Global Credit Crisis. NordicumMediterraneum, 5, 201-233.

Fernandhytia, F., \& Muslichah. (2020). The effect of internal control, individual morality and ethical value on accounting fraud tendency. Media Ekonomi Dan Manajemen, 35(1), 112-127.

Gabbard, G. O. (2014). Psychodinamic Psychiatry in Clinical Practice (Fifth). Arlington, VA: American Psychiatric Publishing, Inc.

Giroux, G. (2008). What Went Wrong? Accounting Fraud and Lessons from the Recent Scandals. Social Research, 75(4), 1205-1238.

KÖKSAL, T. U.-N. K.-İ. (2019). DİJíTALOrtamdakiFinansalHile KontrolündeAdli Muhasebe: BağimsizDenetçilerÜzerindeBir Araştirma. Journal of Turkish Studies, Volume 14(Volume 14 Issue 3), 1609-1627. https://doi.org/10.29228/turkishstudies.22536

Kruskopf, S., Lobbas, C., Meinander, H., Söderling, K., \& Martikainen, M. (2020). Digital Accounting and the Human Factor: Theory and Practice. ACRN Journal of Finance and Risk Perspectives, 9, 78-89. https://doi.org/* Corresponding author. E-Mail address: othmar.lehhttps://doi.org/10.35944/jofrp.2020.9.1.006

Lal Bhasin, M. (2013). Corporate Accounting Fraud: A Case Study of Satyam Computers Limited. Open Journal of Accounting, 02(02), 26-38. https://doi.org/10.4236/ojacct.2013.22006

Malgwi, C. A., \& Rakovski, C. C. (2009). Combating academic fraud: Are students reticent about uncovering the covert? Journal of Academic Ethics, 7(3), 207-221. https://doi.org/10.1007/s10805-009-9081-4

Mathenge, G. D. (2014). An Empirical study to Measuring Corruption and Integrity in Kenyan Police Agency: An Ethical Perspective. Public Policy and Administration Research, 4(2), 67-79.

Montesdeoca, M. R., Medina, A. J. S., \& Santana, F. B. (2019). Research Topics in Accounting Fraud in the 21st Century: A State of the Art. Sustainability Journal, 11(1570), 1-31. https://doi.org/10.3390/su11061570

Mustafidah, N. (2020). Determinants of Employee Whistleblowing Intentions in Indonesia: Applying Theory of Planned Behavior. The Indonesian Journal of Accounting Research, 23(2), 241-262. https://doi.org/https://ijar-iaikapd.or.id/ | 10.33312/ijar.xxx

Nettle, D. (2007). Personality: What Makes You The Way You Are. OUP Oxford.

Nugraha, S., \& Susanto, E. (2018). The Fraud Behavior from the Perspectives of the Fraud Triangle: an Indonesian Case Setya Nugraha. Asian Association for Public Administration Annual Conference (AAPA 2018), 191(Aapa), 113-120.

Okoye, E.I. \& Gbegi, D. O. (2013). Forensic Accounting: A Tool for Fraud Detection and Prevention in the public sector. International Journal of Academic Research in Business and Social Sciences, 3(3) $1-19$ 
Proceedings of the International Conference On Ummah:

Digital Innovation, Humanities And Economy (ICU: DIHEc) 2020

https:/doi.org/10.30874/ksshr.5

accounting students: An application of the theory of planned behaviour. Journal of Financial Crime, 27(2), 477-492.

Purnamasari, P., \& Amaliah, I. (2015). Fraud Prevention: Relevance to Religiosity and Spirituality in the Workplace. Procedia - Social and Behavioral Sciences, 211(September), 827-835.

https://doi.org/10.1016/j.sbspro.2015.11.109

Said, J., Alam, M. M., Ramli, M., \& Rafidi, M. (2017). Integrating ethical values into fraud triangle 
Proceedings of the International Conference On Ummah:

Digital Innovation, Humanities And Economy (ICU: DIHEc) 2020

https:/doi.org/10.30874/ksshr.5

theory in assessing employee fraud : Evidence from the Malaysian banking industry. Journal of International Studies, 10((2)), 170-184. https://doi.org/10.14254/2071-8330.2017/10-2/13

Segal, S. Y. (2016). Accounting frauds - review of advanced technologies to detect and prevent frauds. Economics and Business Review, 2(16), 45-64. https://doi.org/10.18559/ebr.2016.4.3

Soltani, B. (2014). The Anatomy of Corporate Fraud: A Comparative Analysis of High Profile American and European Corporate Scandals. Journal of Business Ethics, 120(2), 251-274. https://doi.org/10.1007/s10551-013-1660-z

Tsao, W., \& Chang, H. (2010). Exploring the impact of personality traits on online shopping behavior. African Journal of Business Management, 4(9), 1800-1812. https://doi.org/http://www.academicjournals.org/AJBM

Utomo, L. P. (2018). Kecurangan Dalam Laporan Keuangan “ Menguji Teori Fraud Triangle .” Jurnal Akuntansi Dan Pajak, 19(01), 77-88.

Wallang, P., \& Taylor, R. (2012). Psychiatric and psychological aspects of fraud offending. Advances in Psychiatric Treatment. https://doi.org/10.1192/apt.bp.111.008946 